\title{
Poznanie dramatyczne
}

ABSTRACT. Krajewska Anna, Poznanie dramatyczne [Dramatic cognition]. "Przestrzenie Teorii” 3/4, Poznań 2004, Adam Mickiewicz University Press, pp. 43-69. ISBN 83-232-1454-9. ISSN $1644-6763$.

The author describes the problem of dramatic cognition against the background of the concept of the dramatic model of literary studies arising from this discipline's own uncertainty about its research procedures, changes occurring within the literary theory discourse and the mechanisms of the theory of cognition concerning the cognition of art and the world. The author discusses application of the category of drama in the modern theory of literature. She also emphasises the fact of unsovability and transgression connected with the theatrical executive instruction of the drama, making it possible to show the play between the reality and the fictionality of the world expressed in the toposes of "theatre-picture", "theatre-figure of the world" and the model of "theatre without the world". The author also adduces the epistemological metaphors of the lamp, the mirror, and the screen.

Zarówno w świecie współczesnej sztuki, jak i w obszarze refleksji o jej regułach dokonującej się w ramach filozofii, estetyki czy teorii literatury dominują, jak się wydaje, dwie ważne tendencje - które starałam się przedstawić we wstępie do poprzedniego numeru „Przestrzeni Teorii” - tj. niepewność oraz wynikająca z niej pośrednio dramatyczność. Nierozstrzygalności ontologicznej, antropologicznej czy teoriopoznawczej towarzyszy wahanie i błądzenie jako świadomie przyjęty sposób uprawiania nauki, z polifonicznością jako cechą artystycznych kreacji łączy się dialogowość jako typ dyskursu teoretycznego. Szeroko pojęta niepewność prowadzi bowiem do poczucia dramatyczności jako istoty świata, sposobu bycia, właściwości tworzenia.

Teoria literatury uzyskuje coraz częściej przymiotniki precyzujące jej charakter odnoszące się do pojęć związanych z ruchem i niestabilnością. Anna Łebkowska w książce Między teoriami a fikcją literackq przywołuje - zgodnie $\mathrm{z}$ komentarzem zamieszczonym $\mathrm{w}$ przypisie „określenia funkcjonujące w literaturoznawstwie zachodnim $\mathrm{i}$ amerykańskim wprowadzone w nasze życie badawcze przez Annę Burzyńską"1: teoria ruchoma, przemieszczona, praktyka teoretyczna. Dodajmy do nich jeszcze jeden przymiotnik: dramatyczna.

Dramatyczna teoria literatury wyrasta bowiem - w moim przekonaniu - zarówno z niepewności własnych procedur badawczych dyscypliny,

${ }^{1}$ A. Łebkowska, Między teoriami a fikcjq literackq, Kraków 2001, s. 22. 
jak i z koncepcji epistemologicznej, która nasze procesy poznawcze wiąże ze specyfiką poznania dramatycznego i opisuje w artystycznych kategoriach dramatu. Interesujące jest bowiem zobaczenie problemu dramatyczności od strony przemian w obrębie dyskursu danej dyscypliny (co sygnalizowałam poprzednio w związku z niepewnością), jak i poprzez opis mechanizmów teoriopoznawczych dotyczących poznawania sztuki i świata (nad czym przede wszystkim chciałabym skupić się obecnie).

Przywołany przeze mnie w tekście o niepewności pomysł Włodzimierza Boleckiego, aby dramat uczynić punktem wyjścia w myśleniu o współczesnym literaturoznawstwie ${ }^{2}$, powinien zaowocować bogatą literaturą. W tym duchu pisze także w zamieszczonym $w$ niniejszym numerze „Przestrzeni Teorii” artykule Danuta Ulicka, która pokazuje przejście od narracyjnej do nienarracyjnej koncepcji literaturoznawstwa. Czyni to jednak, obierając za punkt centralny pojęcie narracji i odwołując się do przykładów zmian w obrębie gatunku powieściowego.

Zachowując pokrewieństwo myślenia o kierunku przemian zachodzących w teorii literatury, spróbujmy odwrócić tę perspektywę i zaproponujmy przyjrzenie się im od strony poetyki dramatu. Widziałabym bowiem w podejściu do teorii (a może i historii czy estetyki) ogromną szansę nowatorskiego odbudowania tak bardzo zaniedbanego przez literaturoznawstwo obszaru, jakim jest teoria dramatu. Stwierdzenie przejścia od narracyjności ku dramatyczności w dyskursie humanistycznym ma stale jeszcze posmak linearności. Problem zaczyna się wtedy, gdy trzeba w kategoriach dramatycznych opisać zjawiska współczesnej kultury, sztuki, literaturoznawstwa. Okazuje się, że odnotowanie ewidentnego faktu dramatyzacji procesów kulturowych, literackich czy estetycznych niesie w sobie dalsze pytania np. o definicje dramatu (zwłaszcza w kontekście olbrzymiej wieloznaczności i pojemności pojęcia), a także o typ dramatu (przywołanie określonej konwencji dramatycznej), a również o związek $\mathrm{z}$ teatrem $\mathrm{i}$ innymi sposobami prezentacji poprzez scenę lub ekran (czyli relacje projektu wykonania $\mathrm{w}$ dramacie $\mathrm{z}$ innymi sztukami).

Sądzić też można, że w przypadku dramatu dużą rolę odegrała praktyka artystyczna (zwłaszcza powstanie teatru absurdu), która wyprzedziła rozwiązania i koncepcje $w$ zakresie widzenia i rozumienia teorii literatury. Tradycyjne cechy liryki i powieści przystawały do monologicznej kultury narracyjnej, ale dopiero dramat okazał się wzorcem określającym nielinearną sytuację kultury ponowoczesnej preferującej

${ }^{2}$ W. Bolecki, Modalność (Literaturoznawstwo i kognitywizm. Rekonesans), w: Sporne i bezsporne problemy wspólczesnej wiedzy o literaturze, red. W. Bolecki i R. Nycz, Warszawa 2002. 
obszar teatralnej gry. Reguły dramatu rozsadziły także dotychczasowy kanon powieściowy, zmieniając strukturę gatunku (np. nouveau roman). Strukturalizm odwoływał się do awangardy jako paradygmatu literackiego, teatr absurdu stał się modelem dla innej, poststrukturalistycznej wizji teorii. Interpretując obie Kartoteki Tadeusza Różewicza, nazwałam ją teorią rozrzucona ${ }^{3}$.

Wizja ponowoczesnego świata zaczęła przypominać sposób kreowania rzeczywistości w dramacie. $\mathrm{Z}$ jednej strony nasiliło się zjawisko używania pojęć i terminologii teatralnej wobec zjawisk natury politycznej, społecznej, psychologicznej w języku potocznym, np. świat bez konsekwencji, teatr działań, gra itp. (por. Erving Goffman Człowiek w teatrze życia codziennego ${ }^{4}$ ). Dramatycznymi terminami agon i gra posługuje się między innymi Jean-François Lyotard w Kondycji ponowoczesnej ${ }^{5}$, aby scharakteryzować współczesny sposób rozumienia i uprawiania nauki po rozpadzie „wielkich opowieści”, które mając status metanarracji, tworzyły wizję nauki jako syntezy nadbudowującej się nad dyskursami szczegółowymi. Kryzys „wielkich narracji” spowodował, że upadła tradycyjna koncepcja nauki dostarczającej wiedzy pewnej na rzecz ponowoczesnej nauki jako gry. Lyotard wprowadza termin „agonistyki powszechnej" na określenie stwarzania reguł przekonywania, zaskakiwania, wprowadzania w błąd przeciwnika w grze, która - dodajmy prowadzi do uzyskania racji cząstkowych tworzonych w procesie będącym projektem budowania pola niepewności. Lyotardowska „scena przedstawienia" łączy ujęcia historyczne związane ze zmianami samej koncepcji teatru 6 .

Od tej strony zatem widać wyraźnie, że w literaturze odżyły echa sztuki Calderona Życie jest snem, które zaczęły pobrzmiewać w nowej wersji. Problem modalności $w$ dramacie stał się problemem teoriopoznawczym. Oto jesteśmy na scenie. Oto toczy się gra czasów, historii, ale także porządków literackich. Teatr zaczyna być widziany jako jedyna forma istnienia (nie odsyła już jak dawniej do swych związków ze światem poprzez pojęcie obrazu lub figury, ale sam zwraca uwagę na siebie, tłumaczy siebie swymi regułami, jest samozwrotnym simulacrum obywającym się bez oryginału).

${ }^{3}$ Pisałam o tym przy okazji interpretacji Kartotek Tadeusza Różewicza: A. Krajewska, Kartoteka bez końca, w: Dramat polski. Interpretacje, red. J. Ciechowicz, Z. Majchrowski, Gdańsk 2001.

${ }^{4} \mathrm{E}$. Goffman, Cztowiek $w$ teatrze życia codziennego, przeł. H. Danter-Spiewak i P. Spiewak, Warszawa 2000.

5 J.-F. Lyotard, Kondycja ponowoczesna, Warszawa 1997.

${ }^{6}$ I. Lorenc, Swiadomość i obraz. Studia z filozofii przedstawienia, Warszawa 2001, s. 184-191. 


\section{Teoretyczne inscenizacje tekstualne i kontekstualne}

Takiemu dramatycznemu obrazowi rzeczywistości zaczął odpowiadać język teorii, która sama uległa zatem - jak kartoteka - rozrzuceniu. Nie sposób dziś stworzyć spójnej, jednoznacznej wizji świata, nie można także odesłać do jedynie słusznego głosu autora, jako instancji opiniotwórczej, ani do jednej teorii, powszechnej i obowiązującej. Teoria literatury przestaje istnieć jako uzurpacja opisu całości. Pozostają teorie i ich relacje. Wszystkie są równocześnie i słuszne, i błędne. Ważne jest napięcie, które wytwarzają pomiędzy sobą. Rolę w opisie tej różnorodności mogłaby zapewne odegrać metodologia rozumiana nie jako historia doktryn, ale jako filozofia nauki, pokazująca różne ujęcia teorii w zależności od systemów estetycznych, kontekstów filozoficznych, dylematów etycznych epoki. Teoria staje się równocześnie praktyką i próbą, eksponuje zatem - jako swoje narzędzie i podstawę bytu - interpretację. Wydaje się, że w tym kierunku podążają książki wieloautorskie traktowane jako serie, np. „Latarnik” Henryka Sienkiewicza. Interpretacje pod red. Tadeusza Bujnickiego i Haliny Bursztyńskiej, Katowice 1984, Czytanie Schulza pod red. Jerzego Jarzębskiego, Kraków 1994, Czytanie Herberta pod red. Przemysława Czaplińskiego, Piotra Sliwińskiego, Ewy Wiegandt, Poznań 1995, „Panny z Wilka” Jarostawa Iwaszkiewicza pod red. Ingi Iwasiów i Jerzego Madejskiego, Szczecin 1996 itp. Prezentują dzieło, ale i równocześnie sposoby mówienia o nim. Serie zastępują syntezy historyczne. Dominuje w nich ujęcie dramatyczne - prezentacja bez komentarza, a ściślej inscenizacja tekstualna, ponieważ pokazywane teksty poddane uprzednio zabiegom redakcyjnym, montażom i układom znajdują się w kompozycyjnej ramie. Serie przypominają nieco technikę zmiennych punktów widzenia, która zawsze dramatyzowała prozę. Ważne są nie tylko same interpretacje, ale też ruchomy kontekst lektury, możliwość wyjęcia, usamodzielnienia, wysłuchania osobno i w dialogu każdego tekstu. Natomiast na poziomie dziedziny wiedzy teoria została rozrzucona poprzez zabiegi interdyscyplinarne. Przedmiot badań nie należy do jednej dyscypliny. Różne nauki oświetlają go inaczej. Wnioski tworzą się na pograniczach, pomiędzy. Istnieje jeszcze zjawisko odwrotne. Ta sama dyscyplina ogarnia różne przedmioty badań, np. estetyka filozoficzna, literacka lub estetyka w naukach ścisłych (Dirac). Niczym w przestrzeni teatralnej reflektor oświetla każdorazowo inny szczegół, czasem wiązka promieni pada na scenę, kiedy indziej kieruje się ku widowni. Swiadomość istnienia obszaru w mroku i pola światła może dopiero wydobywać wszystkie odcienie szarości, gry półtonów, rozjaśnień i zmierzchań. 
Mówiąc o dramatyczności współczesnej kultury, sztuki, uprawiając nową wizję przemieszczonej, ruchomej, rozrzuconej teorii literatury, rozwijając praktykę teoretyczną czy proponując rodzaj transgresyjnej estetyki, odwołajmy się zatem najpierw do wieloznacznego pojęcia dramatyczności.

Dramat może być przydatną kategorią literaturoznawczego opisu, ale i okazać się pułapką metaforycznych nadużyć. Jesteśmy współcześnie świadkami paradoksalnej sytuacji, gdy przy znikomym zainteresowaniu literaturoznawstwa problemem teorii i metodologii dramatu terminologia związana $\mathrm{z}$ tym rodzajem literackim, jak scena, gra, maska, aktorstwo, agon, teatr, opanowała różne dyskursy: literackie, filozoficzne, socjologiczne.

W kategoriach dramatycznych można widzieć też relacje między sztukami, a zwłaszcza proces ciążenia ku teatrowi zachodzący w sztukach plastycznych. Krytyka artystyczna od lat pięćdziesiątych nazywała tego typu dokonania, stosując nazewnictwo rodem $\mathrm{z}$ dramatu np. action painting, zdarzenia i akcje, tzw. events, happening, performance. Odświeżano tym samym myślenie o scenie jako miejscu działania, reinterpretowano pojęcia maski, gry, roli, pozoru, autentyczności i udawania?

Nie bez przyczyny terminologia teatralna, rzec by można, opanowała literaturoznawstwo. Temat ten zasługuje na osobne, szerokie opracowanie. Choć analogie dramatyczne bądź teatralne znane są od wieków, umacniają je dzisiaj różne nauki, rozwijając lub polemizując z użyciami poprzedników. Karierę zrobiły np. wywodzące się z muzyki pojęcia homofonii i polifonii wprowadzone przez Michaiła Bachtina do opisu narracji personalnej w powieści (Poetyka powieści Dostojewskiego) oraz wywodzącego się z kultury teatru zjawiska karnawału w literaturze nazwanego jako proces estetyczny karnawalizacją (Twórczość Franciszka Rabelais'go). Bardzo trafnie zauważył Bolecki, że kategoria dialogowości Bachtina, przystająca do dramatu, opisała paradoksalnie pewien etap rozwoju prozy ${ }^{8}$. Nie sposób dziś pisać o dramatycznym literaturoznawstwie, pomijając ustalenia Bachtina. Pojęcia dramatyczne odsyłają jednak do róźnych zjawisk i metodologii. Dominują określenia neutralne w użyciu metaforycznym, np. kognitywistyczna „konstrukcja sceny” lub dekonstrukcjonistyczne „inscenizacje tekstualne”. Język prezentowanych teorii staje się przez to obrazowy, nacechowany, przemawiający do wyobraźni. Jesteśmy świadkami niszczenia tzw. „przezroczystości” stylu naukowego podtrzymującego postulat tzw. „obiektywizmu” dyscyplin badawczych. Sądzić można, że metaforyka nie szkodzi, lecz wręcz przeciw-

${ }^{7}$ Por. G. Dziamski, Awangarda po awangardzie, Poznań 1995, s. 103.

${ }^{8}$ W. Bolecki, op. cit. 
nie, aktywizuje czy nawet umożliwia procesy poznawcze. Obrazowość języka nauki (warto zwrócić uwagę na rolę wizualnej prezentacji pojęć $\mathrm{w}$ fizyce) sprzyja wyjaśnianiu i pojmowaniu zjawisk i procesów. Metaforyka nie musi stać w sprzeczności ze ścisłością i logiką sądów. Humanistyka jest dziś wielostylowa i dopuszczenie elęmentu literackości w języku teorii zbliża ją do ujęć w kategoriach dramatycznej polifoniczności. Stosowanie właśnie terminologii teatralnej ma głębokie podłoże tkwiące, jak już była o tym mowa, w sposobie rozumienia relacji świata i teatru. Wracają dawne toposy literackie „teatru obrazu” i „teatru figury” świata. Teatr dziś zastępuje świat, określa pozór jako jedyną rzeczywistość. To szeroki i skomplikowany temat dotyczący „światów możliwych” i roli poszukiwań szansy dotarcia do istoty bytu poprzez realne rzeczy, które stają się teatralnymi rekwizytami, poprzez sylleptyczny podmiot aktorski, którego doznania są prawdziwe i równocześnie symulowane w świecie fikcji. Dramat staje się matrycą teoriopoznawczą.

Niekiedy zdarza się i tak, że można zestawić zupełnie odrębne sposoby rozumienia i użycia dramaturgicznej terminologii.

Pojęcie dramatu zjawia się we współczesnej myśli filozoficznej coraz częściej w związku z próbą opisu natury ludzkiej kondycji. Oparta na filozofii dialogu (Martin Buber, Franz Rosenzweig, Emmanuel Levinas) ${ }^{9}$ koncepcja Józefa Tischnera wyłożona w Filozofii dramatu ${ }^{10}$ mówi zatem o dramatycznym poznaniu jako heroicznej próbie pokonania wewnętrznie tragicznej egzystencji ludzkiej. W przyjętej przez filozofa z Podhala wizji dominuje ujęcie uniwersalne, rozważania wybitnego myśliciela i teologa mają za zadanie określić istotę tego, co ludzkie, poprzez dramatyczne odniesienie ku transcendencji. Rozważania nie prowadzą do wniosków dotyczących współczesności, lecz starają się objąć ponadczasową istotę człowieczeństwa w jego dynamicznej naturze.

Inaczej postępuje Zygmunt Bauman, który wprowadza pojęcie dramatu, wiążąc je ze współczesnym, ponowoczesnym sposobem przeżywania życia. Odwołując się do refleksji Jean-François Lyotarda dotyczącej otwartej przestrzeni-czasu wiecznego „teraz” i wszechobecnego „tutaj”, pisze, że w otwartej przestrzeni-czasie „wieść można życie jedynie na sposób dramatyczny". Bauman widzi sens $\mathrm{i}$ istotę dramatu nie w jego wymiarze tragicznym, ale w związku z jego scenariuszowym, czyli moźliwym do powtarzania charakterze. Sam dramat jest zatem tylko grą:

wie się cały czas, że brak wiary zawiesza się jedynie na czas trwania przedstawienia, że zainwestowana ufność może być w każdej chwili wycofana. Nie istnieje więc nic nieodwoływalnego, nieodwracalnego $\mathrm{w}$ dramacie; pozorna nie-

9 Obszerny wybór tekstów prezentuje: Filozofia dialogu, wybór, oprac., przedm. B. Baran, Kraków 1991.

$10 \mathrm{~J}$. Tischner, Filozofia dramatu, Kraków 1998. 
odwołalność sztuki dramatycznej jest sama tylko pewną grą, pewną iluzją, a zatem zdarzeniem odwoływalnym. Dramat jest pewną ciągłą, nigdy nie kończącą się, wiecznie powtarzaną p r ó b ą śmiertelności rzeczy i ludzi, ludzkich stanów posiadania i ludzkich osiągnięć. I na zawsze pozostanie on pewną próbą, nigdy nie stając się „realną rzeczą". Jak można by rozpoznać to, co rzeczywiste, w świecie, który pozostaje permanentnie w nastroju dramatycznym? ${ }^{11}$

Zatem nie tylko „wszystko na sprzedaż, ale także „wszystko na próbę". Skoro naszym udziałem jest forma życia teatru, moźna powiedzieć, że świat ten nie oferuje żadnej pewności, lecz - jak pisze Bauman - także żadnej bezradności. Także - jak to ujął cytowany przez Baumana Michel Maffesoli - „w teatralności nic nie jest ważne, ponieważ wszystko jest ważne"12.

Według Tischnera zatem pojęcie dramatu uruchomiało krąg semantyczny związany z tragizmem, tragedią, dramatyzmem jako działaniem, napięciem, akcją. Dramat tedy scala, pokazuje perspektywę, ku której zmierzamy, prowadzi do anagnorisis.

Zdaniem Baumana natomiast, akcent pada na techniczną stronę zapisu dramatu jako scenariusza, a to $\mathrm{z}$ kolei pociąga za sobą myślenie w kategoriach powtarzalności, niegotowości, ponawiania. Tym razem dramat dzieli, skazuje na niepewność i ustawiczną próbę.

$\mathrm{Na}$ stosowanie określeń scenicznych w socjologii zwraca uwagę np. Clifford Geertz w znanym szkicu $O$ gatunkach zmaconych ${ }^{13}$. Autor przywołuje obrzędową teorię dramatu (Jane Harrison, Francis Fergusson, T.S. Eliot i Antonin Artaud) prowadzącą ku związkom teatru i religii oraz wymienia ideę czynności symbolicznych (Kenneth Burke) wiodącą ku łączności teatru z retoryką, dramatu z perswazją, trybuny ze sceną.

Geertz łączy nurt analiz społecznych, w których występuje analogia dramaturgiczna, z badaniami humanistów, którzy, jak pisze nieco humorystycznie, „wiedzą przecież coś niecoś o teatrze, mimesis i retory-

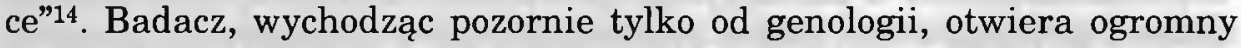
obszar współczesnych dyskusji literaturoznawczych, w których pojęcia dramatu - teatru - gry - czy sceny wyznaczają skomplikowane obszary związane przede wszystkim z dylematami teoriopoznawczymi (zwłaszcza zmianami dotyczącymi interpretacji mimesis, kryzysu reprezentacji, powoływania fikcyjnych konstrukcji zaświadczających realność tworzonych światów itp.) oraz naturą ponowoczesnego dyskursu teoretyczno-

$11 \mathrm{Z}$. Bauman, Ponowoczesność, czyli dekonstruowanie nieśmiertelności, w: Postmodernizm a filozofia. Wybór tekstów, red. S. Czerniak i A. Szahaj, Warszawa 1996, s. 162.

12 Z. Bauman, op. cit, s. 162.

13 C. Geertz, O gatunkach zmqconych, w: Postmodernizm. Antologia przekladów, red. R. Nycz, Kraków 1997, s. 224-229.

${ }^{14}$ C. Geertz, op. cit., s. 229. 
literackiego (związanego z kryzysem metajęzyka na rzecz dramatycznego modelu wypowiedzi). Oba te kierunki pokazują wagę kategorii teatralności w naszym życiu.

$\mathrm{Na}$ gruncie filozofii problematykę teoriopoznawczą podejmuje Irena Lorenc, która w swej książce Świadomość $i$ obraz. Studia z filozofii przedstawienia, pisze $\mathrm{z}$ pozycji filozofa o problemach żywo interesujących zarówno literaturoznawców, jak i estetyków. Praca Lorenc zasługuje na szczególną uwagę, ponieważ autorka wypowiadając się na temat przedstawienia, sama wprowadza do opisu kategorie teatralne, np. sceny (rozumianej, po pierwsze - jako podłoże uzewnętrzniania i ukazywania się, po drugie - nie tyle jako obszar, ile jako granicę tego, co pomię$\mathrm{dzy}$, po trzecie - jako miejsce urzeczywistniania się przedstawienia w jego znakowej strukturze zastępowania, które jest zarazem odobecnieniem i uobecnieniem (de-prezentacją i re-prezentacją) oraz po czwarte jako miejsce neutralizacji kwestii istnienia: przedstawienie nie jest ani tym, co rzeczywiste, ani tym, co fikcyjne, iluzyjne czy nieprawdziwe; jest ono poza tymi rozróżnieniami, jednocześnie każdemu z nich podlegając"15. Lorenc dodatkowo ilustruje filozoficzne rozważania odwołaniami do tragedii antycznej, traktowanej jako model epistemologiczny. „Splaszczenie tragedii $\mathrm{w}$ zachodniej kulturze to urzeczywistnienie modelu Platonowskiego: zwycięstwa logosu nad hybris, nad sferą ludzkiego błędu. Istotnym wymiarem greckiej tragedii bylo sąsiadowanie logosu i hybris w ich wzajemnym napięciu. [...] Hybris, szaleństwo jako doświadczenie nierzeczywistości świata lub jako nieadekwatne doświadczenie rzeczywistości , zostaje wchłonięte przez logos"16.

Trawestując Geertza, można by powiedzieć, że wraz z naszą zmianą myślenia o myśleniu zmienilo się myślenie o poznaniu, a to z kolei zmieniło także myślenie o związkach wiedzy $z$ literaturą. $W$ konsekwencji literaturoznawstwo $\mathrm{z}$ narracyjnego przechodzi w dramatyczne. Metajęzykowa refleksja o literaturze przekształca się $w$ dramatyczną teorię literatury.

Dramatyczność w teorii oznacza także rodzaj panowania nad kontekstem. Czytanie tekstu w zderzeniu z przemieszczonym punktem odniesienia przypomina zmiany dekoracji w teatrze. Inscenizowanie kontekstu staje się nierzadko wartością interpretacyjną porównywalną jedynie $\mathrm{z}$ adaptacją sceniczną. Szeroko zakorzenił się zwyczaj publikowania tekstów wraz $\mathrm{z}$ ich wersjami, wzbogaconymi o zdjęcia rękopisów, zapisków i notatek autorskich, komentarzy, przedmów, wywiadów, rysunków, uwag, skreśleń, montaży i cięć. Tworzy się pewna "otoczka”

${ }^{15}$ I. Lorenc, op. cit., s. 108.

16 Tamże, s. 49. 
tekstowa, rodzaj ruchomego kontekstu, który wpływa na wizję utworu, ale też zachowuje pozorny status zewnętrza, komentarza, który równocześnie należy i nie należy do tekstu. Charakter tych „uzupełnień” porównać można do dramatycznych didaskaliów. Oto biografia dzieła, dramat narodzin tekstu. Do podstawowego mechanizmu poruszenia kontekstu należy akt korekcji. Od momentu autorskiego zawahania, wycofania się, zmiany decyzji zależy nowe ukształtowanie całości, która znów po chwili może się rozsypać. Jedno skreślone słowo przemieszcza nagle resztę materii językowej tekstu. Po korekcji wszystko jest inne, nic już nie może znaczyć tak samo. Stworzona zostaje szansa dla ujawnienia niewyrażonego. Zostaje odsłonięte puste miejsce po wymazywanym i ono właśnie uzyskuje sens, zwraca na siebie uwagę napięcie między tym, co usunięte, co zastąpione, a tym, co wniesione, obce, inne. Korekcja, nie tylko w wymiarze chwytu retorycznego, ale także akcji plastycznej, jest rodzajem teatru walki, starć wersji starej z nową, olśniewającego pomysłu i jego nieudanej realizacji, zapisu kanonicznego i brulionowego. Wstydliwie ukrywane, poprawiane, wypróbowywane, ułomne staje się partnerem czystego, ostatecznego, gotowego w rozgrywce o doskonałość. Kategorię zmiany wypiera przenikanie, gra wymazywań i nanoszeń, palimpsestowych odkryć „drugiego dna” i stałych powrotów na spokojną powierzchnię tekstu. Migotliwa walka znaczeń odsyła w głąb sceny.

Korekcję i palimpsestowość można by uznać za odmianę Derridiańskiego rozsunięcia. Termin Derridy rozsunięcie ma teatralny rodowód, kojarzy się nieodparcie $\mathrm{z}$ kotarą, kurtyną. Zaglądając za kulisy, oglądamy tzw. przestrzeń przysceniczną czy może jednak podglądamy świat. Gdy aktor patrzy na widownię przez rozsnuty czy wycięty mały otwór w kurtynie, zdaje się, że widzi nie widownię, lecz ocenia spektakl rozgrywany przez widzów. Kto jest realny - on czy widzowie? Widownia, jest zorganizowana semiotycznie, ma klakierów, gryzie cukierki, ogląda swe stroje, czyli realizuje zsemiotyzowane już normy towarzyskie itp. - jakże ważne np. w epoce baroku. Rozsunięcie pozwala zobaczyć. Zobaczyć, czyli poznać. Toteż ważna jest estetyka sceny jako miejsca realnego i wyimaginowanego zarazem.

Oba pojęcia rozszerzają grę kontekstem o ruch „w głąb”. Rozsunięcie jest zatem $\mathrm{w}$ dramatycznym sensie aktem poznania, wejrzeniem do środka, zatarciem różnicy między wnętrzem a zewnętrzem. Przypomina się obraz René Magritte'a Terapeuta (1937). Iluzjonista bez twarzy, z nasuniętym głęboko melonikiem, rozsuwa poły brązowej peleryny, odsłaniając zamiast klatki piersiowej klatkę $\mathrm{z}$ parą gołębi. Ukazanie wnętrza można zinterpretować zgodnie z poetyką surrealistyczną jako odwołanie się do podświadomości. Ciekawsze jest jednak zobaczenie, poprzez metaforę unaocznionego gestu rozsunięcia, rzeczywistości pogranicznej, ro- 
dzącej się na styku, na krawędzi, w ramie. W teatrze świadomość istnienia odrzuconej, ale istotnej przestrzeni przyscenicznej nadaje dopiero sens scenie. Poznanie dramatyczne, niczym w metaforach teoriooznawczych Michela Foucaulta, jest zawieszone między gestem-próbą dotarcia do istoty tego, co „osłonięte woalem” lub skazane na „uwięzienie w klatce"17.

\section{Dramat jako problem nierozstrzygalności i transgresji}

W przypadku dramatu możliwa jest sytuacja wskazywania na siebie samego jako synonimu świata i tekstu jednocześnie. Sens pojęcia dramat jest wieloznaczny - znaczy kondycję ludzką i gatunek literacki. Scena pozwala raz odnieść się bezpośrednio ku rzeczom, raz ku tekstom. Teatralna perspektywa nadaje rzeczom tekstową naturę, by zaraz $\mathrm{w}$ tekstowym świecie odnaleźć żywą materię pulsującą prawdziwym istnieniem.

Przedartystyczna warstwa w sztuce - pisze Theodor W. Adorno - stanowi jednocześnie memento jej antykulturalnej skłonności, jej podejrzliwości wobec siebie jako antytezy świata empirycznego, która pozostawia świat empiryczny bez wyjaśnienia. Wybitne dzieła sztuki zmierzają do tego, by mimo wszystko wcielić w siebie ową wrogą sztuce warstwę. Tam, gdzie jej, podejrzewanej o infantylność, brakuje: gdzie uduchowionemu muzykowi kameralnemu brakuje ostatniego śladu zwyczajnego skrzypka, a pozbawionemu iluzji dramatowi ostatniego śladu czaru kulis, sztuka kapituluje. Również nad Końcówkq Becketta unosi się obiecująco kurtyna; sztuki teatralne i praktyki reżyserskie, które ją eliminują za pomocą bezsilnych chwytów, próbują przeskoczyć własny cien. Chwila, w której unosi się kurtyna, jest wszakże oczekiwaniem na apparition ${ }^{18}$.

We współczesnym dramacie polskim najpełniej eksponuje dylemat podwójności, z którego nie można znaleźć wyjścia innego, jak tylko bycie w środku, nawet nie na granicy, lecz w rozsunięciu - Tadeusz Różewicz. W sztukach dramaturga - niczym w scenie z kurtynami z Aktu przerywanego, które na przemian podnoszą się i opadają - toczy się nie tylko gra $\mathrm{z}$ konwencjami teatralnymi, ale filozoficzna dysputa o postaci świata. Różewiczowskie rozsunięcie kurtyny ma charakter Derridiański. Dramatyczne działania sytuują np. wiersz między utekstowieniem a personifikacją. Różewicz wychyla się raz ku definicji dramatu przypisującej mu charakter trwałego elementu bytu, raz ku jego fikcjonalnej naturze,

${ }_{17}$ M. Foucault, Powiedziane, napisane. Szaleństwo i literatura, wybór i oprac. T. Komendant, przeł. B. Banasiak i in., Warszawa 1999, s. 36, 37.

$18 \mathrm{Th}$. W. Adorno, Teoria estetyczna, przeł. K. Krzemieniowa, Warszawa 1994, s. 150 i 151. 
synonimu literackości - ma się wrażenie, że chciałby to zrobić rówocześnie ${ }^{19}$. Pogodzić odgraniczone, zobaczyć rzecz w zwarciu. Jakby powiedział cytowany już raz Foucault, „osłonięte woalem” i/lub „zamknięte w klatce". Dla Różewicza cząstka literatury jest cząstką świata, jest bytem i tekstem. Autor Kartoteki, pisząc o literaturze, wypowiada się na temat postaci bytu. Równocześnie i nierozstrzygalnie dramat oznacza świat i tekst. Tekst ma naturę świata, świat tekstu. $\mathrm{Na}$ śmietnik wynosi poeta zużyte $\mathrm{w}$ procesie pisania papiery ze śladami swoich niegotowych form wierszy, by zaraz potem odnajdować te skrawki i wiązać w popękaną całość w procesie recyclingu. Nic nie jest stałe, między naturę tekstu i świata wkrada się sen. Niepewność ontologiczna uprawomocnia gest odwiecznego dramatyzmu ludzkiego losu i dramatyzmu kultury tekstu. Gdy przyjmiemy: „niczego nie ma poza tekstem”, zakładamy, że i świat ma tekstową naturę. Swiat jawi się jako Księga. Teatr oznacza świat. Ale dalej idąc tym tropem - teatr jest jedynym światem. Wyjście poza teatr jest wyjściem ku niepewności epistemologicznej, odszukać można prawdę jedynie w samym poszukiwaniu transcendencji (mimo milczącego Boga lub/i przez pismo Boga).

Dramat może być jedynym światem tylko wtedy, gdy uzależni się go nie od postaci bycia tekstem, lecz tekst od bycia doświadczanym - pisanym i czytanym przez czlowieka (pisarza, czytelnika, badacza). Wtedy gubią się granice między bytem a tekstem, osobą a literaturą. Dramat kondycji ludzkiej jest dramatem zamknięcia w świecie nierozstrzygalnego epistemologicznie tekstu. Poznanie dramatyczne to doznanie nierozstrzygalności.

Grę dwoma planami - rzeczywistości i pozoru - do perfekcji opanował angielski dramaturg Tom Stoppard. Zwłaszcza takie sztuki, jak Rosencrantz $i$ Guildernstern nie żyja, Pani Hapgood czy Arkadia traktują na różne sposoby o relacji teatru i świata w perspektywie, jakby ją mogła nazwać Zofia Mitosek „stadium” (a może lepiej niezgodnie z cytatem) - „studium kryzysu mimetycznego”. Efekt realności okazuje się w istocie strategią mimetyczną ujawniającą mechanizm semiotyczny: ,jeśli mimesis jest relacją przedmiotowo-podmiotową, to w efekcie realności znika podmiot i przedstawienie, pozostaje sam przedmiot, a właściwie tylko jego iluzja. To, co estetyka oraz teoria aktów mowy określały jako "zawieszenie świata», interpretowano tu jako jego niekończące się odsunięcie czy wręcz nieobecność" ${ }^{20}$. Jedna przestrzeń i odległy czas zbliżać się zaczną do innej przestrzeni i późniejszego czasu. Zmieniać, skracać się

19 I. Górska, Dramat jako filozofia dramatu. Na przykladzie twórczości Tadeusza Różewicza, Poznań 2004.

20 Z. Mitosek, „Mimesis” - Między udawaniem a referencjq, „Przestrzenie Teorii” 2002, nr 1, s. 25. 
będzie odległość między nimi. Aż w końcu wetną się w siebie, jak przystające do siebie puzzle na chwilę przed tym, gdy nakładając się na siebie, pokryją swoje czasy i obszary. „Zbierając nowe, gubimy stare, jak podróżni, którzy cały swój dorobek muszą nieść w rękach, a - to, co gubimy, podnoszą inni, ci, którzy idą za nami. Ta procesja jest bardzo długa, a życie bardzo krótkie. Umieramy w marszu. Ale poza marszem nie ma nic, więc $w$ zasadzie nic nie ginie na zawsze. Zaginione sztuki Sofoklesa odnajdą się we fragmentach albo je kto inny w innym języku napisze. Starożytne receptury przeciw chorobom też się gdzieś odnajdą. Odkrycia matematyczne, które mignęły w otchłani dziejów, znów się kiedyś objawią"21.

Dramat pokazuje nam problem nierozstrzygalności i transgresji jeszcze i w innym znaczeniu, w sensie, nazwijmy go wręcz metafizycznym. Dramat jest światem nie tyle przekraczania granic, ich znoszenia ich przez powtórzenie. Uświadamia on wtedy sytuowanie się w środku między światem realnym a fikcją, między nadaniem a odbiorem, między wyrażaniem a niewyrażalnością.

Gilles Deleuze pisze:

Istnieje tragizm i komizm powtórzenia. Powtórzenie pojawia się zawsze dwa razy, raz w wydaniu tragicznym, drugi raz w charakterze komicznym. W teatrze bohater powtarza właśnie dlatego, że oddzielony jest od zasadniczo nieskończonej wiedzy. Wiedza ta jest w nim, tkwi w nim głęboko i działa w nim, działa jednak jako rzecz ukryta, jako przedstawienie zablokowane. Różnica między komizmem i tragizmem dotyczy dwóch elementów: natury wypartej wiedzy, która jest bądź bezpośrednią wiedzą naturalną, zwykłymi danymi zmysłu wspólnego, bądź straszliwą wiedzą ezoteryczną; a także sposobu, w jaki osoba jest jej pozbawiona, sposobu, w jaki „nie wie ona, że wie”. Problem praktyczny w ogóle polega na tym, że ta nieznana wiedza powinna być przedstawiona, powinna opanować całą scenę, nasycić wszystkie elementy sztuki, zawrzeć w sobie wszelkie moce przyrody i ducha; zarazem jednak bohater nie może sobie jej przedstawiać, przeciwnie, powinien ją przekuć w czyn, zagrać, powtórzyć. Aż do szczytowego momentu, nazwanego przez Arystotelesa „rozpoznaniem”, w którym powtórzenie i przedstawienie splatają się ze sobą, zderzają, nie mieszając wszak właściwych im dwóch poziomów - kiedy jedno odbija się w drugim, żywi się drugim, i kiedy wiedza przedstawiana na scenie i powtarzana przez aktora zostaje rozpoznana jako ta sama ${ }^{22}$.

Powtórzenie w dramacie jest więc pomyłką i olśnieniem jednocześnie. Edyp musi doświadczyć, a więc pokonać granicę między sobą a in-

21 T. Stoppard, Arkadia. Wynalazek miłości, przeł. J. Limon, posłowie R. Pawlowski, Gdańsk 1998, s. 46, 47.

22 G. Deleuze, Różnica i powtórzenie, przel. B. Banasiak i K. Matuszewski, Warszawa 1997 , s. $45-46$. 
nym, by dokonać się mogła pomyłka. Tylko bowiem poprzez zbłądzenie (hamartia) dochodzi do (roz)poznania (anagnorisis), które oznacza nie tylko deszyfrację kodu losu, ale i realizuje się jako akt iluminacji pozwalający na bezsłowne (przebiegające w milczeniu) i niewidziane (realizujące się $\mathrm{w}$ ciemności, rozgrywające się poza wzrokiem) pojęcie tajemnicy istnienia.

Transgresyjność dramatu ma wiele wymiarów. Najoczywistszym jest ten, że dramat otwiera się na inne sztuki. Arystotelesowskie opsis i melos uznane przez interpretatorów za pojęcia związane $\mathrm{z}$ oprawą sceniczną, tkwiące $\mathrm{w}$ tekście $\mathrm{i}$ skierowane równocześnie na zewnątrz, wykraczające poza wąsko rozumiany świat przedstawiony, związane raczej z projektem wykonawcy ${ }^{23}$ - otwierały dramat, przemieszczały granice. W innym wymiarze dramat znosił czy co najmniej rozchwiewał opozycję wnętrza i zewnętrza już poprzez swoją budowę zakładającą didaskalia, tekst poboczny, mówienie na stronie itp. Czy didaskalia można uznać za glosę, uczynić z nich margines, czy istotną partię dzieła? Didaskalia dramatyczne rozważane w perspektywie dekonstrukcjonistycznej poetyki marginesu zasługują na szczególną uwagę. Konstrukcja dramatu bowiem sprawia, że zdyskredytowaniu ulega opozycja wnętrze i zewnętrze. Nie bez przyczyny to właśnie $z$ plastyki przejęte, wykorzystane w teatrze np. Tadeusza Kantora, pojęcie ambalażu dałoby się zastosować jako konstrukcja formy pustej.

Przekroczenia w sztuce współczesnej prowadzą w dwóch kierunkach - ku rzeczywistości realnej („czy nawet najbardziej abstrakcyjne utwory malarstwa, z uwagi na swój materiał i jego wizualną organizację, nie ciągną ze sobą resztek przedmiotowości, którą chcą wycofać z obiegu") i ku jej zanikowi: ku ciszy, milczeniu, nieobecności („Pojawienie się tego, co nieistniejące, jak gdyby istniało, skłania do pytania o prawdę sztuki. Samą swoją formą obiecuje ona coś, co nie istnieje, obiektywnie i zgoła nieporadnie zgłasza roszczenie, iż skoro się ono przejawia, to musi być również możliwe"). Mówiąc cytatami $\mathrm{z}$ rozważań Adorna ${ }^{24}$, pokazać można ten wahadłowy ruch od realności ku nieobecności i z powrotem od braku ku przejawianiu się istnienia".

Zaczęło się wszystko u progu XX wieku, gdy rzeczywiste przedmioty, ready-mades Duchampa, futurystyczne i dadaistyczne słowa na wolności, fragmenty rzeczywistości zdegradowanej i biednej, wszelkie kolaże, assamblaże, ambalaże ogarnęły sztukę, ale ów „cytat z rzeczywistości” do-

${ }_{23}$ J. Ziomek, Projekt wykonawcy $w$ dziele literackim a problemy genologiczne, w: Problemy teorii dramatu i teatru, wybór i oprac. J. Degler, t. 1, Wrocław 2003.

24 Th. W. Adorno, op. cit., s. 151, 152. 
prowadzony został w końcu do sytuacji granicznej, czyli formy pustej25. Ostatnim bastionem realności pozostał ambalaż, czyli opakowanie (które było dramatycznym wskazaniem ramy, określeniem modalności i jako granicy tekstu, dzieła, sceny teatralnej i jako ogarnięcie domyślanej, tajemniczej całości, świata). Ambalaż igrał dwoma znaczeniami: byciem odpadem, śmieciem, przeznaczonym na wyrzucenie opakowaniem, które istnieje chwilę tylko i istnieje tylko po to, by zostać zmięte, jak papier, rozerwane, podarte, odrzucone, piękne na moment - skazane na przemiał oraz bycie próbą przedstawienia nieobecności, braku, pustki, ciszy, a zwłaszcza w malarstwie, śladu po przedmiotach lub po ludziach we wnętrzach. Nie to jest ważne, co pozostaje przedstawione, ale to, czego ubyło, czego brak. Znikające z lustra odbicie, opustoszałe po wyjściu ludzi pokoje, rzeczy bez duszy, bez życia, wyczyszczone, ustawione, utrzymane w idealnym porządku, będące funkcją pamięci, tęskniące za człowiekiem. Tworzy się swoista dramaturgia nieobecności. Sądzić można, że zaczyna się ona w nowoczesnej dramaturgii od Antoniego Czechowa zwłaszcza ostatniej sceny z Wiśniowego sadu, gdy wyjechali już wszyscy i słychać tylko głuchy stuk siekier za oknem.

W teatrze można prześledzić fascynację „cytatem z rzeczywistości” jako próbą sceny, jako reżyserowaniem realności np. $u$ naturalistów. Wyszła z tego najfantastyczniejsza konwencja teatralna zawieszenia poczucia, że oglądamy atrapę, nie świat.

Dzisiaj złudzenie realności wraca $\mathrm{w}$ kulturze masowej $\mathrm{w}$ postaci $\mathrm{np}$. reality show. Rzeczywistość poniżona, zdegradowana do show jako wskazania i popisu równocześnie, nie dotykając bytu, staje się grą, widowiskiem, niekiedy odsłonięciem reguł i ucieczką z planu gry.

Łatwo sobie uświadomić, że plan kompozycji jest przejściem umożliwiającym zakwestionowanie granic świata fikcji i realności. Projekt dramatu to projekt nierozstrzygalności. Dramat zawierający w sobie wizję teatru i aktorstwa stawia na symulację. Daniel Gerould za Baudrillardem pisał o aktorze symulancie ${ }^{26}$. Zataczamy znów nieoczekiwany krąg, wracając do Arystotelesa, który definiował sztukę jako rodzaj oszustwa, w którym oszukiwany staje się bogatszy od oszusta. Aktor może udawać chorobę, miłość, zazdrość itp., ale też może stawać się symulantem, wytwarzając w sobie stany traktowane jako oznaki. Na scenie aktor gra symulanta lub się nim staje naprawdę. Stąd ta fascynująca granica umowy złej wiary.

${ }^{25}$ Por. B. Tokarz, Między destrukcjq a konstrukcjq. O poezji Srečka Kosovela $w$ kontekście konstruktywistycznym, Katowice 2004, s. 41.

${ }^{26}$ D. Gerould, Zawód: pacjent, czyli o teatrze symulantów, przeł. J. Sieradzki, „Dia$\log ^{\prime \prime} 1988, \mathrm{nr} 7$. 
Z tak rozumianej dramatyczności wynikają dalsze konsekwencje. Dramat znosi liniowość, jego istotę określa nieciągłość. Podzielony na akty i sceny, odsłony lub obrazy, zawsze odsyła do ujęć fragmentarycznych. Jak żaden inny gatunek, ze swej natury jest prezentacją części. Dramat operuje estetyką zerwania, fragmentu, uwidacznia i podkreśla znaczenie progowości. A więc nie perfekcja, lecz rozwój, nie nieodwracalność i galowa premiera, lecz powtórzenie i próba są jego udziałem. Można też powiedzieć inaczej, że na tym podwójnym działaniu polega urok dramatyzmu. Interesujące jest owo rozpięcie między zdążaniem ku premierowej gali a powtórką wpisaną natychmiast już w prapremierę. W teatrze nie można zastygać w bezruchu. Zawsze dzieje się coś nowego, zawsze może być inaczej. Dramat, projektując całość, nigdy jej nie osiąga, komponowany $\mathrm{z}$ fragmentów, oparty na podziałach, wskazuje na ruch pomiędzy nimi, na interesującą sferę tego, co pomiędzy sceną a kulisą, aktem a antraktem, obrazem a ramą. Stąd problemy delimitacji w dramacie należą do jednych z ważniejszych elementów estetyki świata teatru. Zastanowić się warto, czy - jak napisał Bolecki - dramatyczna konstrukcja świata wyklucza ramę modalną ${ }^{27}$. W moim odczuciu modalność w dramacie nie jest osłabiona, ale paradoksalnie wzmocniona, np. w tradycyjnym pudełkowym modelu teatru (kurtyna, antrakty, odsłony) a $\mathrm{w}$ średniowiecznym czy awangardowym przez obszar gry, miasto, mansjon. Problem polega na tym, iż dramat udaje, że nie ma ramy, że jest pozbawiony tej modalności (brak czwartej ściany). Złudzenie samodzielności świata przedstawionego w dramacie powoduje brak osoby, medium, które niczym narrator w powieści czy podmiot liryczny w liryce panuje nad tym światem. Kategoria dramatu mogłaby być rozpatrywana jako problem estetyki teatralnej tzw. „projektów miasta” od średniowiecznego placu miejskiego jako teatralnej sceny, przez awangardowe futurystyczne skandale aranżujące festiwal ulicy, po ponowoczesny camp znoszący obiegi kultury wysokiej i niskiej. Tu już zachodzą komplikacje związane $\mathrm{z}$ koniecznością uwzględnienia konwencji teatralnych i dramatycznych.

Bauman, wprowadzając do swoich rozważań kategorię dramatyczności, poprzedza ją obrazowym porównaniem stylu życia związanego z pielgrzymką i koczowaniem. Życie pielgrzyma wyznacza projekt i plan, jego przestrzeń określa obszar związany, ciągły, widziany jako koneksja. Nomada natomiast, idąc od oazy do oazy, zatrzymuje się w miejscach niezwiązanych. Baumanowskie metafory pokazują dramatyczno-teatralną naturę dróg, które przemierzamy. Najwyraźniej widać to poprzez współczesną interpretację dramatu stacji (od Strindberga Do Damaszku po Różewicza Pułapkę). Idąc od stacji do stacji, mamy złudzenie piel-

${ }^{27}$ W. Bolecki, op. cit. 
grzymowania, nigdy jednak nie osiągamy celu, odkrywamy możliwość powtórzenia. Wracamy do początku drogi. Współczesny dramat stacji nie daje możliwości odkupienia.

Często w słownictwie literaturoznawczym słowa występują bez dookreśleń, np. agon, scena, teatr itp., chociaż czasami warto postawić pytanie o typ sceny czy model teatru. Foucault w Szaleństwie i literaturze mówi o scenie teatru klasycznego, Derrida w Piśmie $i$ różnicy przywołuje teatr okrucieństwa Artauda. Przy pytaniu o modalność nie da się uchylić rozwiązań historycznych. Same teorie dramatu także niewolne były od uwarunkowań teatralnych (por. spór, czy Stefania Skwarczyńska, tworząc teatralną teorię dramatu, opierała się na modelu realistycznego teatru, czy towarzyszyło badaczce myślenie o dokonaniach Wielkiej Reformy? ${ }^{28}$.

Gdy przyjrzeć się uważnie przywołanym tu sądom, odnieść można wrażenie, że dotyczą różnych cech wieloznacznego słowa dramat. Dramat w znaczeniu tragicznego wymiaru ludzkiej kondycji (Tischner), w rozumieniu fikcjonalności, gry (Geertz, Lyotard, Goffman), powtarzalności (Deleuze), próby (Bauman), filozoficznego projektu ustanawiania sceny (Lorenc), ale może przede wszystkim nierozstrzygalności poprzez wciąż na nowo i niejednoznacznie ustalaną granicę między prawdą a fikcją, życiem rzeczywistym i realnością sceny (Derrida). Dramat staje się modelem świata. Teatr przestał dawno być obrazem świata oraz figurą świata. Dziś teatr obywa się bez świata i równocześnie świat ma teatralną naturę. Teatr bez świata określa sytuację nierozstrzygalności, ponieważ znosi, zaciera i wciąż na nowo ustala granicę między realnością a fikcjonalnością. Dlatego poznanie współczesne musi mieć dramatyczną naturę. Demaskujemy udawanie po to, by móc w nie znowu uwierzyć. Próbujemy - życia, teatru, nieśmiertelności. Wciąż umieramy na scenie, by móc zaistnieć w życiu. Funkcja katarktyczna nieobca jest współczesności.

Status teatru $\mathrm{z}$ jednej strony, a także natura dramatu jako gatunku operującego projekcją sceny $\mathrm{z}$ drugiej, odzwierciedlają dylematy teoriopoznawcze związane $\mathrm{z}$ tendencjami $\mathrm{w}$ sztuce współczesnej współgrają wręcz z dzisiejszym myśleniem o naturze świata, literatury, sztuki.

\section{Poznanie dramatyczne - między olśnieniem a złudzeniem}

Hasło „poznanie dramatyczne" wymaga komentarza ze względu na ukrytą w nim wieloznaczność. Poznanie dramatyczne dotyczyć bowiem może samego przedmiotu badań literaturoznawczych (natura tego przedmiotu ma charakter dramatyczny), schematów teoriopoznawczych

28 Por. dyskusję: Co się stato z teorią dramatu w Polsce, „Teatr” 1997, nr 3. 
uruchamianych przez różne konwencje dramatyczne (od antycznego anagnorisis po postmodernistyczne epifanie negatywne) lub dramatu rozumianego jako matryca teoriopoznawcza łącząca poprzez teatr poznanie rzeczywiste, zmysłowe, bezpośrednie, empiryczne $\mathrm{z}$ poznaniem artystycznym ( $w$ opisie specyfiki tego doświadczenia pośredniczą często metafory epistemologiczne dotyczące doznan wzrokowych - okna, szyby, obrazu, lampy, lustra, ekranu).

Rozważając pytania o przedmiot literaturoznawstwa, Ryszard Nycz stwierdził, że „Określenie [...] przedmiotu literaturoznawczego poznania winno uwzględniać jego funkcjonalno-konstruktywistyczny charakter językowy oraz występowanie w trzech głównych zakresach dziedzinowych: literatury, kultury, ludzkiego doświadczenia"29. Wydaje się, że te trzy obszary, ku którym wychyla się, czy na których funkcjonuje dzieło: artystyczny, kulturowy, doświadczenia przynależącego ludzkiej kondycji, łączy w szczególny sposób dramat. Tylko bowiem on poprzez projekt wykonania zakładający realizację teatralną wpisuje się równocześnie w szereg artystycznie ukształtowanej sztuki słowa, kulturowy model sceny z różnorodnością jej konwencji oraz zmysłowe, realne doznanie, będące doświadczeniem świata rzeczywistego przekształcającego się na naszych oczach $\mathrm{w}$ procesie artystycznej kreacji w sztukę. W działaniu tym uczestniczymy duchowo poprzez imagincję oraz fizycznie doznając rzeczywistości poprzez własne ciało (tylko bowiem w teatrze możemy dotknąć realnego kształtu świata, który okazuje się równocześnie jego obrazem).

Poznanie poprzez dramat łączy w sobie poznanie literackie ze specyficzną projekcją (projektem?) doznania zmysłowego (patrzenie jako typ poznawczego doświadczania $\mathrm{i}$ analizowania świata wpisane jest $\mathrm{w}$ reguły dramatu poprzez jego związek z nastawieniem na wykonanie, najczęściej teatralne). Dramat uruchamia bowiem specjalnie silnie te cechy odbioru, które przekraczają próg między poznaniem literackim a rzeczywistym. Taką kategorią pośredniczącą byłoby oglądanie realnych ludzi (aktorów) i rzeczywistych przedmiotów (rekwizytów) na scenie. Wypowiedź dramatyczna związana jest silnie z kategorią deixis. W swoich rozważaniach poświęconych deixis Boris Uspienski ${ }^{30}$ pominął płaszczyznę aktorstwa. Co zrobić, kiedy aktor mówi ,ja"? Na co natomiast wskazuje ,ja”, gdy aktor gra aktora? Czego wtedy dotyczy deixis, do jakiego

${ }^{29}$ R. Nycz, Pytania o przedmiot literaturoznawstwa. Wystapienie na Zjeździe Polonistów, Kraków 22-25 września 2004 (cytat za streszczeniem komputerowym). Por. także R. Nycz, Kulturowa natura, slaby profesjonalizm. Kilka uwag o przedmiocie poznania literackiego $i$ statusie dyskursu literaturoznawczego, w: Sporne $i$ bezsporne problemy, op. cit.

${ }^{30}$ B. Uspienski, wykład poświęcony deixis wygłoszony w Poznaniu 24 lutego 2002 r. 
planu się odnosi - widocznego czy ukrytego, co firmuje - prawdę czy fikcję? Poznanie dramatyczne znów odsłania, ujawnia podwójną naturę. (Adorno przywołuje nawet kategorię poznania deiktycznego).

Fenomenem teatru jest w istocie (używając terminu Derridy) nierozstrzygalność. Okazuje się zatem teatr bezpośrednim dotknięciem świata, które niczym wstęga Möbiusa niepostrzeżenie przechodzi w fikcję. Przytaczana przez Derridę scenka „Pierrot zabójcą swej żony” z Mimique Mallarmégo pokazuje, jak zawieszona zostaje granica między prawdą a fikcją. Teatr, oznaczając świat, równocześnie kwestionuje jego istnienie - umieszczony między rzeczywistością a ekranem - rozgrywa się $\mathrm{w}$ istocie jakby po drugiej stronie lustra. Nie między okiem a rzeczą, lecz między okiem - sceną/ lustrem/ ekranem/ - a rzeczą.

Wydaje się, że dzieje literatury - zwłaszcza XX-wiecznej - dałyby się opisać $w$ perspektywie poznania dramatycznego. Nie bez przyczyny filozofowie współcześni (Heidegger, Deleuz, Lorenc) wracają wciąż do interpretacji Edypa Sofoklesa zwracając uwagę na aspekt poznania, rozumiany jako gra pozoru i rzeczywistości. Życie Edypa było pozorem i złudą wyborów, które musiał odrzucić wraz ze wzrokiem, aby przebić się ku prawdzie. Strukturę tragedii Sofoklesa przejmują filozofowie, by z tragedii poznania uczynić opis dramatu ludzkiej kondycji zawieszonej między nadzieją na iluminację a koniecznością uwikłania w życie jako grę złudzeń. Między rzeczywistością a pozorem staje sztuka.

Ryszard Nycz w perspektywie poetyki epifanii rozważa literaturę nowoczesną jako tę, która odsłania swój status dyskursu granicznego. „Literatura - zwłaszcza literatura nowoczesna - staje się tym specjalnym miejscem, gdzie świat wkracza dopiero w przestrzeń doświadczenia i zarysowuje na horyzoncie ludzkiego poznania; i tym szczególnym momentem ludzkiego doświadczenia, w którym procesowi nastawania «bezimiennej" realności zachodzą drogę znaki, akty kategoryzacji i nadawania sensu. Tam i wtedy właśnie ślad staje się tropem; literatura «zaszyfrowanym zapisem» rzeczywistości"31.

Przyjmijmy na użytek niniejszego szkicu, że modernizm, czyli nowoczesność obejmowałby rozleglą formację artystyczno-intelektualną, sięgającą do romantycznej tradycji estetycznej i wyczerpującej swoją moc oddziaływania $\mathrm{w}$ drugiej polowie $\mathrm{XX}$ wieku ${ }^{32}$, postmodernizm, ponowoczesność wiążąc natomiast $\mathrm{z}$ przełomem lat pięćdziesiątych na Zachodzie. Anick Brillant-Annequin swój artykuł tytułuje wprost Teatr absurdu: narodziny wspótczesnej estetyki ${ }^{33}$, a Adorno wykorzystuje kate-

31 R. Nycz, Literatura jako trop rzeczywistości. Poetyka epifanii $w$ nowoczesnej literaturze polskiej, Kraków 2001, s. 12.

32 Tamże, s. 88.

${ }^{33}$ A. Brillant-Annequin, Teatr absurdu: narodziny wspótczesnej estetyki, „Ruch Literacki" 1995, z. 4. 
gorię absurdu jako kategorię estetyczną związaną z próbą wyrażania w sztuce tego, co w dotychczasowy sposób nie otrzymywało możliwości wyrazu. Analizując Końcówkę Becketta, pisał: „Między negatywnością zawartości metafizycznej i zaciemnieniem zawartości estetycznej zachodzi relacja, a nie tożsamość. Negacja metafizyczna nie dopuszcza już żadnej formy estetycznej, która by samą sobą wywoływała afirmację metafizyczną, a mimo to potrafi stać się zawartością estetyczną, determinować formę"34. Wydaje się bowiem, że wraz z nową falą, nouveau roman, a przede wszystkim z teatrem absurdu dokonał się zauważalny przełom w literaturze, teatrze, innych sztukach, pociągając zmianę myślenia i ugruntowując pomału, to, co Lyotard w tekście Odpowiedź na pytanie: co to jest postmodernizm? określa jako stosunek do niewyrażalnego:

[...] estetyka modernistyczna jest estetyką wzniosłości, aczkolwiek pełną nostalgii: pozwala ona bowiem czynić aluzję do nieprzedstawialnego jedynie pod postacią nieobecnej treści, podczas gdy forma, dzięki jej poznawalnej spoistości, w dalszym ciągu prowadzi czytelnika lub widza ku przyjemności bądź pocieszeniu. [...] Postmodernistyczne będzie więc to, co w modernistycznym przedstawieniu odsyła do nieprzedstawialnego; to, co wyrzeka się pocieszenia podsuwanego przez poprawne formy, odrzuca zgodę na smak, umożliwiający wspólne doświadczenie nostalgii za nieosiągalnym; to, co poszukuje nowych przedstawień, nie po to, by się nimi delektować, lecz po to, by lepiej odczuć istnienie nieprzedstawialnego ${ }^{35}$.

$\mathrm{Z}$ pełną świadomością ryzyka uproszczeń i omyłkowości rozpoznań można by pokusić się o stwierdzenie, że niewyrażalność, pustka, milczenie, absurd staną się pojęciami granicznymi otwierającymi w obie strony - ku modernizmowi i ku ponowoczesności - obszar kruszącej się pewności, trwałości, nieprzenikliwości literackiego poznania. Będą one zatem jakimś stanem zerowym, od czego, jak od pustej przestrzeni, w której mogło zabrzmieć pierwsze słowo, zaczną odbijać się wszelkie działania w sztuce.

Możemy wyznaczyć dwa typy poznania dramatycznego: jeden określony przez formację modernistyczną (która zakłada istnienie drugiej strony dyskursu) oraz postmodernistyczną (opartą na zwątpieniu w możliwości uchwycenia realności świata).

Tedy, w odróżnieniu od modernistycznego stosunku do niewyrażalności związanego $z$ poznaniem epifanicznym (epifaniczna struktura ontologiczno-poznawcza) przypiszemy postmodernistycznemu, ponowoczes-

34 Th. W. Adorno, op. cit., s. 634.

35 J. F. Lyotard, Odpowiedź na pytanie: co to jest postmodernizm?, przel. M. P. Markowski, w zbiorze: Postmodernizm. Antologia przekladów, wybór, oprac. i przedmowa R. Nycz, Kraków 1997, s. 60. 
nemu podejściu do nieprzedstawialnego poznanie dramatyczne oparte na epifanii niemożliwej (inscenizowanie niewyrażalności) ${ }^{36}$.

Estetyka modernistyczna charakteryzowałaby się jeszcze poprzez model opowieści i dyskurs w przewadze narracyjny. Lyotardowska „poznawcza spoistość formy" sugerowałaby te cechy. Postmodernistyczne inscenizowanie odkrywa po drugiej stronie dyskursu zaporę pozoru. Znakomitym przykładem ponowoczesnego dramatyzmu (tak $\mathrm{w}$ sensie tragizmu, jak w znaczeniu kształtowania dyskursu) są sztuki Thomasa Bernharda oraz jego powieść Kalkwerk pokazująca - inscenizowanie niewyrażalnego.

O ile opisane przez Ryszarda Nycza poznanie epifaniczne określało możliwość osiągnięcia (za pośrednictwem literatury) w literaturze pewnego typu doświadczenia metafizycznego, o tyle poznanie dramatyczne pozyskujące teatralność jako kategorię pośredniczącą w projekcji iluzji realnego świata umożliwia doznanie nierozstrzygalności ontologicznej. Gra dwoma planami rzeczywistości i pozoru (fikcji, iluzji, reprezentacji) właściwa teatrowi i projekcja tej gry zawarta w planie dramatu pokazują przewrotnie, że rzeczywistość teatralna jest rodzajem realności wytwarzającej pozór i równocześnie fikcją będącą namacalną, zmysłowo doświadczalną realnością. Jacques Derrida pisał „Gdzie w civitas szukać tej zagubionej jedności spojrzenia i głosu? W jakiej przestrzeni będzie można jeszcze ją usłyszeć? Czy teatr, który łączy widowisko z dyskursem, nie mógłby przejąć pałeczki jednomyślnego zgromadzenia?"37.

Ponowoczesne poznanie dramatyczne - jak się wydaje - pokazuje rodzaj epifanii niemożliwej lub negatywnej. Szczególnie cennym przykładem byłaby tu twórczość Stanisława Ignacego Witkiewicza. Rzecz nie leży tylko $\mathrm{w}$ wyborze gatunków, lecz w przynależności Witkacego do orientacji niezgodnej z czasem historycznym, w którym wypadło mu żyć. Witkacy okazał się pisarzem łączącym modernizm, który opuszcza z ponowoczesnością, którą zapowiada. Choć przynależy do orientacji modernistycznej, dystansuje się od nowoczesności, jak się wydaje, pod wieloma względami wpisując się w estetykę ponowoczesności (nie tylko jako artysta, ale też jako teoretyk sztuki ${ }^{38}$ ).

${ }^{36}$ Por. R. Nycz, Literatura jako trop rzeczywistości, op. cit. Od razu zaznaczyć jednak trzeba, że nie da się wprowadzić podzialów czystych, granic wyrazistych, definicji jednoznacznych. Swiadczyć by to mogło pośrednio o w istocie płynnej granicy między nowoczesnością a tym, co post. Zwłaszcza jeśli weźmiemy pod uwagę wprowadzoną przez Nycza kategorię epifanii negatywnej oraz refleksje na temat osoby w nowoczesnej literaturze (przede wszystkim w kontekście opisu dwóch tendencji fikcjonalizacji i empiryzacji głosu autorskiego w ich dramatycznej relacji w literaturze XX wieku).

37 J. Derrid a, O gramatologii..., przeł. B. Banasiak, Warszawa 1999, s. 395.

38 Por. A. Krajewska, Witkacego inscenizacje tekstualne, „Pamiętnik Literacki” 2002, z. 4. 
Nienasycenie można interpretować na różnych płaszczyznach. Z punktu widzenia teoriopoznawczego kategoria stworzona przez Witkacego odsyła ku epifanii niemożliwej. Poznanie epifaniczne nie może mieć tu zastosowania zarówno $\mathrm{w}$ wymiarze romantycznej epifanii rozumianej jako iluminacja, olśnienie (postacie pragną przez doznanie uczucia metafizycznego osiągnąć Tajemnicę Istnienia, ale, niestety, nigdy nie będzie im to dane. Ból, męka nienasycenia nie gwarantuje im nadziei na oświecenie), jak i współczesnych „małych epifanii”, odkryć w zachwyceniu jednostkowych realności (i tu bohaterowie Witkacego nie zdołają objąć „szarych eminencji zachwytu”, o których rozprawiają bohaterowie Białoszewskiego. Jedyne, co poznają, to obrazek świata jako sztuczną dekorację teatralną).

Nienasycenie jako kategoria estetyczna, rozumiana jako nienasycenie formą, odsyła do pojęć blaknięcia, mgły, wymazywania, niemożliwości zbliżenia się do Czystej Formy, jako pewnej awangardowej utopii jeśli tak nam wolno ją rozumieć.

Nienasycenie oznacza i - co ważne - inscenizuje nieosiągalne. Nienasycenie wyznacza pewien typ doznań związanych z ruchem, procesem, akcją, dynamiką, działaniem, krótko mówiąc, koncepcja nienasycenia odwołuje się do dramatycznej natury (ma dramatyczną naturę). Witkacy kreuje iluminację i równocześnie ją rozbija. Męka nienasycenia projektuje tragiczno-komediową epifanię negatywną. Poznanie jest niemożliwe, ponieważ dotyka nie świata, lecz sztucznego wytworu, nie rzeczywistości powołanej przez literaturę w języku nawet, ale danej w teatrze dekoracji. Wizja "teatru bez świata" oto formuła łącząca Witkacego z postmodernistami. Stąd także można wyprowadzić koncepcję powtarzalności dramatycznej (w znaczeniu Deleuze'a), tyle tylko, że anagnorisis nie dotyka postaci. Rozgrywa się jedynie, jak w Kurce Wodnej - tragedia sferyczna, jak w Matce - niesmaczna sztuka, lub, jak w Janulce córce Fizdejki - historia, która „odwróciła się zadem do pyska”... Postmodernistyczny typ poznania eksponuje teatralne działanie wychodzące od literatury i wracające do niej.

Konstanty Puzyna pytał kiedyś: „czy Witkacy mógł znać Heideggera"? Czy podobnie interpretowałby poezję Hölderlina? ${ }^{39}$ Czy zgodziłby się, że poezja jest dosłownym ustanawianiem bytu, a bycie staje się jawne i uobecnione w procesie rozświetlenia? Poznanie Tajemnicy Istnienia byłoby zatem czekaniem na światło. Witkacy mógłby powtórzyć za Hölderlinem i jego interpretatorem słynne zdanie „Cóż po poecie w czasie marnym”. Witkacy jako dramaturg stale jednak podejmuje zmaganie

${ }^{39}$ M. Heidegger, Objaśnienia do poezji Hólderlina, Warszawa 2004. Por. także C. Woźniak, Martina Heideggera myślenie sztuki, Kraków 2004.

\section{$63 \mid$ Poznanie dramatyczne}


$\mathrm{z}$ materią istnienia i sztuki w poszukiwaniu Heideggerowskiego rozświetlenia.

Wydaje się, że perspektywa wewnątrzliteracka współgra z kierunkiem rozwoju myślenia teoretycznego związanego $z$ reinterpretacją niektórych pojęć poprzez otwarcie ich na teatralność.

Problem poznania dramatycznego można zobaczyć także w związku ze wspólczesnymi teoretycznoliterackimi interpretacjami, które zmierzają do nowego zdefiniowania starej kategorii mimesis. Jeśli - mimo że wydaje się już opisany i wyczerpany - problem mimesis wraca, to jako kwestia przedstawienia ${ }^{40}$. Obie nazwy nawiązują do teatru: pierwsza, tradycyjna, eksponuje udzial mima w odtwarzaniu rzeczy, druga akcentuje scenę jako miejsce gry, ale nie wskazuje żadnej konwencji teatralnej. Przedstawianie jest zatem unaocznianiem, ale i udawaniem. Drugi aspekt, na który zwracają uwagę badacze ikoniczności i mimesis ${ }^{41}$, dotyczy przesunięcia mimesis ze sfery semantyki w sfere pragmatyki (związane także $z$ przejściem od definicji znaku w ujęciu de Saussure'a do przyjęcia rozumienia Peirce'a). Wprowadzenie triadycznego modelu znaku z udziałem interpretanta ma poważne konsekwencje w rozumieniu mimesis. Posłużmy się fragmentami rozważań Zofii Mitosek: „Uwzględnienie czynnika podmiotowego $\mathrm{w}$ konstatacji mimesis radykalnie przemieszcza obiekt badań ze struktury przedmiotu "naśladującego" na konteksty pozaartystyczne, takie jak smak, sytuacja, wiedza odbiorcy" i dalej „Ten podmiotowy aspekt sprawia, że nie będąc ani mimetycznym podwojeniem przedmiotu, ani absolutną prawdą, przedstawienie stanowi mediacje między świadomością a światem. W ten sposób staje się strukturą rozumienia". Wyraźny staje się fakt, że modelem definicji będzie relacja dramatyczna, a nie narracyjna. Myślenie w kategoriach dramatycznych i teatralnych okazuje się bardzo silne i nośne, rzutuje także na język teoretycznoliteracki w zakresie używanej terminologii i metaforyki teatralnej np. „interakcja wciąga odbiorcę w świat przedstawiony, powoduje, że utwór jako literacki spektakl języka staje się dla niego spektaklem świata, który ów język przedstawia" (podkreślenia moje A.K. $)^{42}$. Sama kategoria mimesis widziana jest przez niektórych badaczy (np. Kendall Wallon) jako ,gra w udawanie”.

Może więc jednak na przekór koncepcji łączącej mimesis z porządkiem narracyjnym ${ }^{43}$ powiedzieć, że bardziej niż $\mathrm{z}$ antropologią opowia-

$40 \mathrm{O}$ problemach związanych ze współczesnym podejściem do mimesis patrz: Z. Mitosek, „Mimesis” - między udawaniem a referencjq, op. cit.

41 Por. E. Tabakowska, Ikoniczność: podobieństwo i tertium comparationis, „Przestrzenie Teorii" 2003, nr 2, s. 103.

42 Z. Mitosek, op. cit., s. 33.

43 Por. uwagi Z. Mitosek, "Mimesis" - między udawaniem a referencją, op. cit., s. 45 . 
dania krzyżuje się z porządkiem dramatycznym czy nawet $\mathrm{z}$ antropologią teatru? A może owa wyrażona przez Mitosek niepewność pozostawiająca mimesis w zawieszeniu między udawaniem a referencją dotyczyć by mogła także zawieszenia mimesis między strukturami narracyjnymi a grą dramatyczną i spektaklem?

„Grając na naszych przedstawieniach, wprowadzając nas w stan iluzji, wahania i bezradności, udając i produkując symulakry, poprzez swoją grę zakłóca utarty porządek rzeczy na korzyść niekończącego się poznania - także poznania samej mimesis".

Przytoczona powyżej refleksja badaczki kończąca artykuł odsłania także świadomość faktu dramatycznego charakteru samego dyskursu literaturoznawczego, który pokazuje omawiany problem $\mathrm{w}$ ujęciu procesualnym, dopuszczając udział różnych opcji i metodologii, inscenizując spektakl zmiennych punktów widzenia.

Współczesność przywraca i eksponuje dramat jako ważny gatunek literacki, który nieoczekiwanie, poprzez grę z wpisaną weń projekcją teatralności stał się wzorcem, modelem odzwierciedlającym (mówiąc tytułem książki Konstantego Stanisławskiego) nasze życie w sztuce i (mówiąc slangiem komputerowców) nasze życie w realu.

Podwójna natura dramatu - ku literaturze, ku dyskursowi, ku pi$\mathrm{smu}$, a także równocześnie - ku prezentacji sceny, ku widowisku, ku głosowi każe myśleć o złożoności zjawiska poznania dramatycznego, które określiło szczególnie świadomość epistemologiczną współczesności.

\section{Przed lustrem i ekranem}

Wyobraźmy sobie taką oto sytuację - znaleźliśmy się nagle w renesansowym teatrze mnemonicznym ${ }^{44}$. Chcemy zapamiętać świat, ale mamy doświadczenie człowieka XXI wieku. Spróbujmy przejąć rolę aktora $\mathrm{w}$ wyimaginowanym eksperymencie. Jako badacze stańmy się na chwilę artystami na scenie mnemonicznej przestrzeni. Tzw. „metafory umysłu" podsuwają kierunek. Zacznijmy zatem od podejścia do okna. Albertiańska metafora okna pokazuje, że w procesie przedstawienia zatrzymujemy się na powierzchni szyby. Przez okno widać rzeczywistość, ale szyba przepuszcza i odgradza równocześnie, kieruje nasz wzrok ku bytowi w jego istocie i jednocześnie zaciera wyrazistość kształtów. Oglądamy świat przez szybę z nadzieją, że kiedyś - według słów św. Pawła staniemy przed nim „twarzą w twarz”. Od okna skierujmy się ku wnętrzu pokoju, by zobaczyć go w świetle lampy i odbitego w lustrze. Meta-

${ }^{44}$ W. B. Yeats, Sztuka pamięci, Warszawa 1977. 
fory epistemologiczne M. H. Abramsa „lampy i zwierciadła” uświadamiają zniekształcające znaczenie wewnętrznego „oświetlenia”. „Według jednej koncepcji przedmioty zewnętrzne tylko odbijają się w umyśle - jak w zwierciadle; według drugiej natomiast rzuca on - niczym lampa światło na postrzegane przez siebie przedmioty, tym samym niejako je współtworząc. Metafora pierwsza była znamienna dla głównych nurtów myśli od Platona aż po wiek XVIII; druga jest typowa dla przeważającego w romantyzmie pojmowania umysłu poetyckiego"45. Temat lustra fascynował od wieków. Współcześnie zwracają uwagę refleksje nad jego istotą i sposobem „czytania świata”między innymi Umberto Eco czy Jacques'a Lacana. Ciekawie przywoluje pojęcie lustrzanego odbicia Lorenc w związku z redukcją fenomenologiczną. Dzieje się bowiem tak, że, aby potwierdzić i uwierzytelnić swoje bycie, aby potwierdzić swoje istnienie, musimy mu zatem najpierw zaprzeczyć. To odbicie uwierzytelnia nasze bycie. Bez rzeczy nie ma odbicia. Przed lustrem zawsze znajduje się realna rzecz. Gdy ona znika, znika również zwierciadlany obraz. Nikomu nie udało się jeszcze przesłać swego odbicia w lustrze. Odbicie lustrzane ma charakter przedstawienia, ponieważ równocześnie uruchamia istnienie podmiotu i jego eliminację poza taflę lustra. Inaczej zupełnie rzecz się ma $z$ ekranem, który odrywa podmiot od obrazu. Wyjście z teatru okazało się wejściem do pokoju $\mathrm{z}$ widokiem na ekran ${ }^{46}$.

Różnicę między lustrem a ekranem podkreślał wielokrotnie Jean Baudrillard. „Przed lustrem podmiot inscenizuje siebie jako to, co realne, i to, co imaginatywne. Natomiast świat widziany przez obiektyw, na monitorach, zapośredniczony przez techniki medialne staje się wirtualny - przedmiot "potencjalnie" wydaje siebie i gra swą własną grę"47. Baudrillard nazywa ten stan stanem antropologicznej niepewności. „Stadium wideo zastąpiło stadium lustra"48.

Czy teoriopoznawcze metafory odwołujące się do wzroku dałoby się przetransponować na dźwięk? Można zapytać, jak słyszymy świat? Literaturoznawstwo narracyjne stawiało akcent na dźwięk, czyli słuchanie ciągłej opowieści. Z dramatem związane jest oglądanie. Dramatyczna teoria literatury kieruje się zatem ku wzrokowi. Coraz częściej refleksja

45 M. H. Abrams, Zwierciadto i lampa. Romantyczna teoria poezji a tradycja krytycznoliteracka, przeł. M. B. Fedewicz, Gdańsk 2003, s. 8.

46 V. Sajkiewic z, Pokój z widokiem na ekran, w: Wiek ekranów. Przestrzenie kultu. ry widzenia, red. A. Gwoźdź i P. Zawojski, Kraków 2002.

47 J. Baudrillard, Swiat wideo i podmiot fraktalny, w: Po kinie... Audiowizualność w epoce przekaźników elektronicznych, wybór, wprowadzenie i oprac. A. Gwóźdź, Kraków 1994, s. 253.

48 Tamże, s. 251. 
zostaje przedstawiona w przestrzeni sceny, rozpisana na glosy, aktywna w działaniu i inscenizacji dyskursu. $\mathrm{Z}$ pewnością takiemu ujęciu towarzyszy szybkość przeglądania, ogarniania wzrokiem równocześnie dużego fragmentu, najczęściej „rozegranego” plastycznie tekstu. Model dyskursu przypomina często model strony internetowej.

Dramat zawsze rozszczepiał osobę - (podmiot autorski oddawał głos postaciom). Przypatrzmy się zatem zmianie pokazującej przejście od rozumienia tożsamości w ujęciu narracyjnym do podmiotowości przejawiającej się w wymiarze dramatycznym. Wydaje się bowiem, że nie sposób już dzisiaj rozważać koncepcji tożsamości bez akcentu na dramatyczne stawanie się. On, autor, on, podmiot dramatu, wypowiadal się zawsze i działał poprzez innych, a mówiąc Ricoeurem - doświadczał równocześnie cudzej podmiotowości.

Istotą dramatu jest działanie. Poprzez czyn zbliżamy się do Ricoeurowskiej koncepcji tożsamości, która jest wyraźnie z deklaracji autorskiej narracyjna. Zarówno w znaczeniu la memete, jak i l'ipseite koncepcja tożsamości Ricoeura jest związana $\mathrm{z}$ teorią narracji, uzależniona od czasu, a więc przebiegu linearnego, jest posuwaniem się po linii prostej na zasadzie narastania wiedzy, gromadzenia zasobów, dodawania etapów. Niemniej ukrywa już w sobie wewnętrzne napięcie dramatyczne. Paul Ricoeur pisał, że warunkiem bycia sobą jest możność działania. Sobą jest ten, kto może działać, zarazem wskazując na siebie jako sprawcę działania ${ }^{49}$. Dalej Ricoeur nawiąże do dramatu $\mathrm{z}$ zupełnie innej strony - pokazując koncepcję siebie samego jako innego.

„Właśnie dlatego, że pod wpływem innego człowieka sam dla siebie staję się inny, w innym człowieku - na zasadzie odwrócenia - mogę dostrzec odpowiednik mnie samego: inne "ja”50". Zwrot Ricoeura "Ja to ktoś inny" brzmi dramatycznie, lecz całość koncepcji tożsamości przybiera wyraźnie linearny kształt.

Prawdziwie dramatyczny charakter ma natomiast koncepcja Baudrillarda - podmiotu fraktalnego dająca się wpisać w proponowaną przez Baudrillarda formułę „être en abyme" (bycia w stanie zawieszenia) w odróżnieniu do „mise en abyme" (jako szukania czegoś powyżej).

Baudrillard wprowadza inspirujące rozróżnienie między lustrem a ekranem w związku z ontologią podmiotu. „Wszystko zmienia się zbyt szybko i zbyt mocno, tak, że nie mają one [obrazy itd.] czasu, by powrócić i poddać się refleksji, a w ten sposób nabyć znaczenia. Nie istnieje tu żadna lustrzana scena ani dla zdarzeń, ani dla historii. Media są pew-

${ }^{49} \mathrm{P}$. Ricoeur, O sobie samym jako innym, przeł. B. Chełstowski, oprac. i wstęp M. Kowalska, Warszawa 2003, s. XIII/XIV.

${ }^{50} \mathrm{P}$. Ricoeur, O sobie samym jako innym, op. cit., s. XXVII. 
nym rodzajem skroplenia sekwencji znaczeń, dlatego też pozostaje się na "scenie ekranu». Jest się przed ekranem. Nie jest się już przed zwierciadłem, ono już nie odbija. M y jesteśmy na scenie ekranu; oznacza to, że jesteśmy w punkcie, gdzie nie mamy możliwości spojrzeć na ekran. Odczuwamy fascynację. Jest to pewien sposób oślepienia ekranem, bycia wewnątrz ekranu. [...] Jest się wciągniętym w ekran, jest się simulacrum spojrzenia" 51 .

Przypomina się fascynacja Różewicza nieprawdziwością swego ekranowego wcielenia, zabawna gra $\mathrm{z}$ tym na kanapie i tym na ekranie. Wobec ekranu próbuje zachować się poeta-podmiot wiersza jak wobec lustra. Tyle tylko, że bawi go różnica. Oto - jakby powiedział Baudrillard - „spektakl mózgu”, którym jesteśmy tak zafascynowani. On na ekranie jest kimś innym, nie powiela gestów, nie oddaje spojrzenia. Czy to już jest wciągnięcie w ekran bez możliwości odbicia? Lustrzane lśnienie oślepia, ekran pochłaniając, matowieje, wymazuje. Wymazywanie i mgła. Przedłużenie fraktalne podmiotu nie ma nic wspólnego z lustrem. Dotyczy wszelkich ekranów. Najpierw ekran jest przedłużeniem. Wideo, nagranie, odtwarzanie. Potem występowanie w studio, telewizji. Sytuacją ciekawą są telebimy. Mamy lepszy kontakt z ekranem niż $\mathrm{z}$ osobą. Zniesiona zostaje intymność sytuacji, np. wieczoru autorskiego. „Przyszli zobaczyć poetę” zmienia się w: przyszli zobaczyć obraz poety, ekran z poetą. Na ekranie widzimy więcej, każdy grymas twarzy, drgnienie powiek, nawet defekt skóry. Opanowała nas estetyka zbliżenia i detalu. Komputerowe „maksymalizuj” daje wrażenie reprezentacji świata. W filmach o świecie przyrody (owady, kwiaty) pojawiają się i wręcz dominują efekty przyspieszania i powiększania. Zwiększając, wdzieramy się w świat, wchodzimy w jego wnętrze. Rozpoczyna się dyskusja z obrazem. Poznanie dramatyczne - między rzeczą a obrazem, między maleńką mrówką a wielkim jej obrazem. Widzimy inny wymiar świata. Tak w powiększeniu, jak i w przyspieszeniu, np. sfilmowane rozkwitanie pąków. Literatura od wieków znała tę grę. Estetyka groteski i burleski, hiperboli i miniaturyzacji itp. Ekrany unaoczniły techniki prezentacji świata. Zniknął (prawdziwy?) wymiar świata. Od endoskopu po telebim jesteśmy na ekranie.

Teatr ma charakter lustra, poznanie dramatyczne zawiera w sobie realne (aktor, przedmiot), ale też może iść dalej ku ekranom i monitorom, które przenoszą relację teatralną w sferę wirtualności, w której znika realne, zniesiona jest granica między grą żywego człowieka na

${ }^{51}$ Gra resztkami. Wywiad z Jeanem Baudrillardem przeprowadzony przez Salvatore Mele i Marka Titmarsha, w: Postmodernizm a filozofia. Wybór tekstów, red. S. Czerniak i A. Szahaj, Warszawa 1996, s. 209, 210. 
scenie lub przed lustrem. Zostaje ona zastąpiona jedynie obrazem tej gry. Sytuację poznania teatralnego zastępuje sytuacja poznania postteatralnego. Poznanie dramatyczne obejmuje jedną i drugą sytuację (teatralne, lustrzane, zakładające realność) oraz (postteatralne, ekranowe, zakładające pozór). We współczesnym dramacie mamy zatem tę niepokojącą podwójność poznających postaci, które nie mogą odkryć, że same są postaciami literackimi. Współcześni bohaterowie grają swe role, stając często przed lustrem ciszy i pustym zwierciadłem bez obrazu, monologi wygłaszają na scenie przed niewidoczną czwartą ścianą, na koniec wciągnięci w gładką powierzchnię ekranu doznają jedynie poczucia niepokoju. Co zatem poznajemy? Niepewność ontologiczna - oto stan, który odkrywają postacie. A więc z jednej strony ucieczka od rzeczywistości, realności. Z drugiej chęć powrotu do doświadczania świata.

Kim jesteśmy sami jako podmioty badające literaturę. Od momentu, gdy wiemy, jak bardzo sami poprzez nasze narzędzia odkształcamy badany obiekt, możemy albo $\mathrm{z}$ boku obserwować zapoczątkowane przez nas procesy, albo przyjąć postawę aktora rozgrywającego spektakl teorii. Lorenc cytuje myśl Hanny Arendt, która zauważyła, że w filozofii europejskiej to „obserwator, a nie aktor trzyma w ręku klucz do spraw ludzkich"52. Dziś wydaje się, że myślenie raczej by trzeba związać z pojęciem aktorstwa. Wszystko toczy się w grze, nasze ustanawianie świata wciąż rozbija się o niepewność, wielość i przypadkowość obrazów. Reżyserujemy spektakl, w którym równocześnie gramy jako aktorzy. Ciekawe jest zatem wciąż badanie historii naszych wejść na scenę i ucieczek za kulisy, znikania w oślepiającym świetle reflektorów lub wyrazistego istnienia w cieniu milczącej i niewidocznej przestrzeni przyscenicznej, dziejów naszych zjawień się i nieobecności.

62 I. Lorenc, op. cit., s. 22. 